\title{
Hospitality and the Other: \\ Anglican Schools As Places of Transformative Encounter \\ Tom Wilson
}

\begin{abstract}
This article argues that Anglican foundation schools have a positive impact on pupils' sense of belonging to the wider community by creating safe spaces within which to encounter difference in a positive and transformative manner. The paper is divided into three main sections. First, the context in which the article was written is outlined. Details of the author's two years of fieldwork in a multi cultural Anglican primary school are set out and an understanding of Anglican schools as places which display an authentic outworking of a Christian worldview is explained. Second, the role of Anglican schools as places of encounter is discussed, with reference both to relevant Anglican literature and to the author's own experience of Anglican schools. This includes a substantial discussion of the Anglican understanding of hospitality as the foundation for creating safe spaces for transformative encounters. Hospitality is understood solely in a religious sense, of a Christian school acting as host to those of all faiths and none. Third, the core values of respect, forgiveness and freedom, which support the status of Anglican schools as safe spaces of encounter are elucidated. This involves both examples from the author's fieldwork and also published literature on the topic. Respect is discussed as a foundational value for any encounter with difference, which must be balanced with a willingness to forgive those who react negatively to such encounters. Freedom is understood specifically in the context of freedom of religious belief, reinforcing an understanding that Anglican schools do not engage in proselytising activity. The article concludes by reinforcing the central argument of the paper that Anglican faith schools contribute to a sense of belonging to a wider community through creating safe spaces to encounter the other and taking deliberate steps to engage with that other.
\end{abstract}

\section{What should we do with the Muslim pupils?}

A vicar colleague of mine was told by the headmaster of the primary school in which he was about to take an assembly that two Muslim pupils had just joined the school. 'Better keep them out of the assembly,' the vicar said, 'just in case anyone gets upset.' Another vicar I know challenged his PCC with regard to the Anglican Primary school in their parish: the overwhelming majority of pupils are Muslim. Surely it was the PCC's duty to ensure they were all converted, or at least 'presented with the claims of the Gospel' before they left the school? Are Muslim pupils terrors to be avoided, as in the first example? Are they simply targets for conversion, as in the second? In this article, I will argue that they are neither. They are people made in the image of God, who do need to hear the good news of Jesus, but 
in a way that they can genuinely hear. I would hate my daughter to have Islam rammed down her throat, or to have her excluded from school assembly at the arbitrary wishes of an imam. We need to think carefully about how we engage with Muslim pupils in our primary schools. In this article, I will argue that Anglican schools provide safe spaces in which to encounter the 'other,' and to be transformed through that encounter into understanding those who are different as people with whom to engage positively. Moreover, Anglican schools can present the Gospel of Jesus Christ to pupils, but it must be done in a way that they will actually hear and respond to, which means more than simply saying words in an act of collective worship.

Muslim pupils attend many Anglican schools. As Thompson states, one hears anecdotally of Muslim and Hindu parents chosing to send their children to Anglican faith schools because they at least support belief in God. ${ }^{1}$ Scourfield et al also note Muslim familes who perceived attendance at a church school as being advantageous for their children because they provided opportunities to discuss belief in God, and were partners in the fight against secularism. ${ }^{2}$ This certainly accords with my own experience of talking with Muslim parents, who were positive about their children's school as supporting faith. Every year at the end of term service I would pray for God's blessing on the children as they finished their school year, and Muslim parents would always thank me for doing so, even if the blessing were Trinitarian.

\section{Context}

The paper draws on two years of fieldwork I conducted in a single-form entry Anglican Primary school in a city in the north of England where the majority of pupils were Muslims, originating from a wide variety of contexts, but included a significant number whose families were originally from Somalia and the Yemen. My research investigated their responses to Christianity as encountered in the school. Although my focus was on Muslim pupils, I nevertheless engaged with all pupils, regardless of religious background. My role within the school was as curate in the associated parish church, and also as chair of the school's governing body. This combination of roles meant that although I was an insider in some sense, I was also an outsider, an authority figure of whom some were wary. ${ }^{3}$ During my fieldwork, I was in the school at least three days a week, and often five days. My research consisted primarily of participant-observation ethnographic fieldwork, which was written up daily in a field journal, as well as conducting thirty-one focus groups with all pupils in school years four to six (pupils aged 8-11) and ten semi-structured interviews with their teachers. Class teachers arranged the makeup of the focus groups, and they followed a semi-

\footnotetext{
${ }^{1}$ Thompson, P. (2004). Whose confession? Which tradition? British Journal of Religious Education. 26(1), 61-72, p.64. DOI: 10.1080/0141620032000149926.

${ }^{2}$ Scourfield, J., Gilliat-Ray, S., Khan, A., \& Otri, S., (2013). Muslim Childhood: Religious Nurture in a European Context. Oxford: Oxford University Press, p.128.

${ }^{3}$ On this issue of insiders and outsiders in the study of religion, see McCutcheon, R. T. (1999). The Insider/Outsider Problem in the Study of Religion: A Reader. London: Continuum.
} 
structured group interview format, each group consisting of between two and four pupils. I also taught twelve RE lessons, and analysed relevant official paperwork. The findings were triangulated through a further twenty-eight focus groups, a lesson with a whole class and an additional seven semi-structured interviews with staff. This article therefore draws particularly on experience of an Anglican primary school, but the underlying principles are, I suggest, equally applicable to any Anglican school.

I engaged in my fieldwork in a consciously Christian fashion, regarding it with Moschella as an opportunity to learn more about people made in God's image, as a pastoral practice. ${ }^{4}$ Thus my research utilised data gathered through fieldwork in order to reflect theologically and practically on Muslim negotiation of the Christianity encountered in a particular Anglican school. This paper sits on the boundary between theology and an ethnographic account of fieldwork, which leads, I propose, to a much richer and more fully rounded study. 'Theology without concrete access to how believers live can be empty; mere description of behaviours and events can be theologically blind. ${ }^{5}$ In this article, I will reflect on the theology of hospitality, respect, freedom and forgiveness as key expressions of the Christian faith that will genuinely engage with Muslim pupils.

Before I engage with the substance of my argument, I will first explain how I understand Anglican schools. Although it is common to speak of 'faith schools' as a generic category, there are differences between them, and since I primarily have personal and scholarly knowledge of Anglican schools, I have limited my discussion to them. It is important to recognise that an Anglican school operates with an ethos that is an authentic expression of a Christian worldview. This does not necessarily mean that practice will be unique in comparison with other schools, whether they are those of another faith tradition or have no faith tradition. Cooling argues a case for 'doing God in education' and in response to criticism from Norman explains that he understands distinctively Christian education to mean education that is pedagogically faithful to Christian teachings. ${ }^{6}$ Recognising the difficulty in having to redefine 'distinctive' as meaning 'not unique but faithful to,' I prefer to simply state that Anglican schools operate from an ethos that is an authentic outworking of a broadly Christian worldview. This allows for recognition that not all staff or pupils will profess Christian faith, but that the foundational assumptions from which the school operates are authentic expressions of Christian identity. This accords with research that

\footnotetext{
${ }^{4}$ Moschella, M. C., (2008). Ethnography as a Pastoral Practice. Cleveland: The Pilgrom Press.

${ }^{5}$ Saliers, D., Flueckiger, J. B., Diakité, D. S. \& Seeman, D. E. (2010). Ethnography and Theology: A Critical Roundtable Discussion. Practical Matters 3, 1-14.

${ }^{6}$ Cooling, T. (2010). Doing God in Education. London: Theos.

Norman, R. (2012). Worldviews, humanism and the (im)possibility of neutrality. Oxford Review of Education. 38(5), 515-525. DOI: 10.1080/03054985.2012.722861.

Cooling, T. (2012). Contestable beliefs in education: fairness and/or neutrality. Oxford Review of Education. 38(5), 551-566. DOI: 10.1080/03054985.2012.728977.
} 
indicates although Anglican schools aspire to a particular Christian identity, not all staff necessarily operate from that identity. ${ }^{7}$

\section{Anglican Schools as a hospitable place in which to encounter difference}

Hospitality is by no means a distinctively Christian virtue. Indeed Western Christians have perhaps neglected to practise it as much as they should. Nevertheless, the tradition of hospitality is an important foundation for transformative encounter. Before I develop a more detailed understanding of the metaphor of school as host, I will first tackle possible negative perceptions. First, I note the metaphor of hospitality is used here specifically of the religious character of the school. It is not a reference to the ethnicity of pupils, nor is it intended to imply any sort of status hierarchy. A second criticism might be that hospitality implies a temporary relationship and an imbalance between host and guest. A critic of the metaphor of a school as host could argue that it reduces pupils and their parents into mere temporary guests, those who come and are cared for, but eventually leave, never entering into a relationship between equals. However, a distinction in roles does not necessarily indicate inequality. As Ward observes there is no superiority between guest and host; the distinction is functional, not hierarchical. ${ }^{8}$ Extrapolating to the context of the school where I did my fieldwork, it was clear that the staff, both as a body, and often as individuals, were permanent fixtures, but by contrast pupils and parents changed very rapidly, perhaps only staying for a few weeks. It was not uncommon for less than half of a cohort of children who entered the school in the nursery class (aged four) to remain in the cohort until they left in year six (aged eleven).

There are some limits to the metaphor of hospitality. Some things, such as bullying, racism, sexism, or manipulation of others, are not welcomed. The hospitality offered by the school is always temporary, as pupils stay for a maximum of eight years (from starting in nursery aged four to leaving year six aged eleven). Furthermore hospitality is limited by the number that can be admitted to each class (thirty pupils) and by the expectation that pupils must follow the national curriculum and abide by the certain behavioural standards and rhythm of the school day. The hospitality is not entirely spontaneous or free, but structured. The metaphor is only applied to religious faith, not ethnicity.

Moreover, hospitality is not without its shadow side. Although I support the use of the metaphor within a school context, it cannot be regarded as an entirely unproblematic concept. I have noted the limitations of the metaphor above, but in addition to this,

\footnotetext{
7 Johnson, H. (2002). Three Contrasting Approaches to English Church/Faith Schools: perspectives from headteachers. International Journal of Children's Spirituality. 7(2), 209-219. DOI: $10.1080 / 1364436022000009118$

Johnson, H. \& McCreery, E. (1999). The Church of England Head: the responsibility for spiritual development and transmission of tradition in a multi-cultural setting. International Journal of Children's Spirituality. 4(2), 165-170.

${ }^{8}$ Ward, G. (2005). Christ and Culture. Malden: Blackwell, p.84.
} 
recognise the imbalance of power that is inherent to the host-guest relationship. In the context of hospitality, hosts are more powerful than guests; in a school, staff are more powerful than pupils. In fact, this is one of the reasons why I regard the metaphor of hospitality as apposite to a school, namely that it accurately reflects the imbalance of power present in a school.

Furthermore, the school might abuse its power as host. To give one example from my fieldwork: although the majority of pupils were Muslim, the school never closed during celebration of the two Eids. This meant that during both years of my fieldwork, I encountered examples of Muslim children attending school during celebrations of one of the Eids, in response to the headteacher's request that pupils did not miss school to celebrate Eid. It is questionable whether this was an appropriate action, especially since the children in question were in the nursery. Did the host (the school) abuse power on this occasion? At what point does the school's duty to educate become intrusive into personal, family space? Hosts must be aware of their power and careful in how they use it.

Where exactly does the balance of power lie between guest (pupil) and host (staff)? Normally with the latter, but the former do have the power to resist, disrupt, or even conform in order to get what they want. On $8^{\text {th }}$ May 2012, I look part in interviews for a new member of teaching staff. One of those interviewed had during the previous year (academic 2010/2011) been Learning Support Assistant (LSA) to the highly disruptive year 4 cohort. Now in year five, this group were the class the interviewees were teaching. The class decided they wanted their former LSA to get the job, and were impeccable in their behaviour when he taught them, to the point that their teacher joked with me that he did not know what he had been doing wrong all year, given how well behaved they were being. While their former LSA was teaching them, not one child said a word out of turn, an unheard of circumstance for that class. Moreover, one of the children was overheard encouraging classmates to misbehave when the other candidates were teaching, in order to further improve the chances of their preferred candidate getting the job. These children were well aware of their power to support and disrupt the interview process, and used it to the greatest possible extent. It is a moot point whether they were acting as guests or hosts at this point, but it is clear they were exercising all of the power that they had.

While these limitations of the metaphor of hospitality must be borne in mind, it is nevertheless true that in a world characterised by estrangement, individuals and groups are painfully searching for 'a hospitable place where life can be lived without fear and where community can be found. ${ }^{9}$ Schools can provide just such a place. Nouwen contrasts hospitality with hostility, suggesting a distinctively Christian hospitality aims to create a space 'where the stranger can enter and become a friend instead of an enemy. ${ }^{10}$ As this transformation towards friendship takes place, the distinction between guest and host

\footnotetext{
${ }^{9}$ Nouwen, H. J. M. (1998). Reaching Out. London: Fount, p.43.

${ }^{10}$ Nouwen, H. J. M. (1998). Reaching Out. London: Fount, p.49.
} 
becomes blurred and both can learn from and minister to each other. This is especially true in the relationship between teachers and students. The teacher is the host, charged with creating 'a free and fearless space where mental and emotional development can take place. ${ }^{11}$ In the care of a gracious host, students are thus enabled to not simply memorise information, but to learn more about themselves, in particular to learn that they all have a contribution to make, that they all have something to offer. From this moment of discovery, a teacher then helps the student to develop and deepen these talents, and so better equips the student for life.

This journey of discovery is never without risk, and calls for wise and careful decision making. A host should not become hostage to the guest. Troll explains the process of interfaith dialogue as one involving shared learning, patience, careful attentiveness, as well as open and critical questioning. ${ }^{12}$ Russel suggests hospitality includes empowering outsiders and the marginalised. ${ }^{13}$ I witnessed a number of examples of this during my research. One example came when I was teaching an RE lesson in the run up to Easter. The year four class were discovering, the majority for the first time, how to look up passages in a Bible. For some the process 'look up the name of the book, then find the big number for the chapter, then the small number for the verse' was grasped after a few false starts. For some it was a baffling struggle. But for one Muslim girl it was a transformative moment of discovery: here was something at which she excelled. Most of her schooling was a struggle, but now she had found a task at which she could help her classmates, a rare and precious position to be in. Her teacher, realising the significance of the moment for her, soon had her busily employed assisting her classmates. But as was noted in the paragraph above, the moment of discovery is not enough: the gift must be developed. And so she went home with a request to her parents: could she take a Bible home to further develop this gift? The next day she came back to school smiling ear to ear, and took home the Bible, with a list of verses to explore. A wise host does not simply make a guest feel welcome and at home, she also helps the guest to develop and grow.

A wise host listens to his guests to see if there is anything he can do to further improve their experience, and this is also something I observed. Pupils were regularly asked if they could think of any ways in which teaching could be improved, and one year six pupil suggested a simple adjustment to literacy lessons, asking for less spoon-feeding and more structured freedom to develop his ability as a writer. The teachers recognised the wisdom of the suggestion, and it was promptly adopted across the school. Here the guest gave input to the host, blurring the distinction between them and emphasising their common purpose and goal of equipping the pupils (guests) with the best possible education they could get.

\footnotetext{
${ }^{11}$ Nouwen, H. J. M. (1998). Reaching Out. London: Fount, p.61.

${ }^{12}$ Troll, C. W. (2009) Dialogue and Difference: Clarity in Christian-Muslim Relations. Maryknoll: Orbis Books, p.2.

${ }^{13}$ Russell, L. M. (2009). Just Hospitality: God's Welcome in a World of Difference. Louisville: Westminster John Knox Press, p.4.
} 
Anglican churches and schools are no strangers to negotiation in religious faith. Ward and Coakley document the experience of the 'Littlemore Group' of Anglican clerics who 'devoted themselves simultaneously to scholarship and to the demands of ordinary parish life,' as they engaged with Islam in a wide variety of contexts. As with this article, the metaphor of hospitality is central to their theological reflection, arguing for generous hospitality, where friendship is cultivated for friendship's sake, including 'public friendships' in which Anglican ministers publicly and openly engage with Muslims in order to 'break through the constraints of fear that operate so effectively in British society today. ${ }^{14} \mathrm{~A}$ central argument of the book is a call to radical hospitality, modelled on the example of Jesus, a hospitality which deliberately seeks out those who are very different from the host, and which does not shy away from the difficulties and challenges that such actions entail. Although Ward and Coakley nowhere addresses the specific context of multicultural Anglican schools, the central thesis of hospitality complements the argument that I advance here.

The Church of England utilises hospitality as a central metaphor in its published literature on inter-faith relations. Thus the report Presence and Engagement recognises the importance of a physical presence in geographic localities where those of other faiths are present, stressing the importance of not merely being present, but also engaged with everyone in the community. The report details a number of stories of creative engagement, explaining how individuals and churches have moved out of their personal comfort zones in order to meet with those of other faiths. ${ }^{15}$ Similarly, the report Generous Love argues that we must model our own behaviour on the generous love of God, especially as it is made known to us in the person and actions of Jesus Christ, recognising also that the Holy Spirit is active in the world, often outside the walls of the church and in unexpected places. In practical terms Generous Love argues that we should emulate the 'embassy and hospitality of God,' both going out to engage with others and also welcoming and receiving them. When practising hospitality we must not conceal our own convictions, but express them in a practical way, working hard at breaking down barriers of suspicion and mistrust, realising that 'being embarrassed, perplexed and vulnerable may be part of our calling as both guests and hosts' as we establish relationships of mutual trust, and the sharp distinctions between guest and host blur into reciprocal and mutually supporting relationships. ${ }^{16}$

There are at least three components to such hospitality: presence, engagement and a willingness to take risks, even to fail. I will examine each in turn. In his discussion of the ministry of chaplains, Holm argues that presence is central to chaplaincy. He discusses the promise of divine presence through God's promise to be with his people always, noting that when a chaplain seeks to be present, she is offering a freely given gift of herself, listening,

\footnotetext{
${ }^{14}$ Ward, F. \& Coakley, S. (2012) Fear and Friendship: Anglicans Engaging with Islam. London: Continuum, p.73.

${ }^{15}$ Church of England. (2005). Presence and Engagement: the churches task in a multi-faith society. London: Church of England.

${ }^{16}$ Anglican Consultative Council. (2008). Generous Love: The truth of the Gospel and the call to dialogue. London: Anglican Consultative Council, p.14.
} 
giving and receiving, typified by a readiness to stand in wonder and openness before the mysterious life and gift of the other, where self is subsumed and the needs of the other become paramount. If one is not fully present in a situation, then true hospitality cannot be offered. ${ }^{17}$

Education is not a commodity to be sold, but a service that Anglican schools seek to make available to all. Thus any school is present to and for all who attend, building pupils' social capital through pastoral care and community building, modelling a commitment to care for everyone in need. ${ }^{18}$ The school is an Anglican presence, the main place where the majority of pupils and staff encounter Christian community. ${ }^{19}$ Elbourne suggests three concepts that are integral to Christian presence: rootedness, belonging and narrative. Anglican schools are rooted in the Anglican Christian tradition, securely anchored, but not so firmly held as to become either atrophied or otherwise inflexible. The school belongs in its own neighbourhood, having formed working relationships with parents, local residents and supportive agencies and statutory bodies. It is a clear statement of Anglican presence. ${ }^{20}$

But mere presence is not enough; presence must lead to engagement. Wenger is correct to argue that true learning takes place not in isolation, but in community. ${ }^{21}$ I learn more about self, others and the subject of enquiry when I am not left to learn alone. As Ramadan argues, we cannot remain isolated in ghettos, leading parallel lives insulated from each other; we must leave our comfort zones behind, and engage in meaningful activities together. ${ }^{22}$ The task of education lends itself naturally to such engagement. Cairney, Cowling et al. (2011) detail the initial attempts of the Anglican Diocese of Sydney to begin to develop a theory of Anglican Education. The Australian educational context is very different from the English situation, and so some of their thoughts (for example about how religious education should be conducted) are not applicable. However one central argument is relevant, namely that Anglicans should be interested in the development of the whole person, not simply in transmitting information or enabling students to pass examinations. This is especially clear in the chapter by Jensen (2011), which argues the imago Dei is seen most clearly in the person of Christ, and further that human beings must be cultivated in order to fulfil their calling, and that necessarily includes inducting students into the practices of sociality and cultivating individual gifts and talents.

\footnotetext{
${ }^{17}$ Holm, N. (2009). Toward a Theology of the Ministry of Presence in Chaplaincy. Journal of Christian Education 52(1), 7-22.

${ }^{18}$ Astley, J. (2012). Church Schools and the Church's Service for the Poor. In H. Worsley (Ed.), Anglican Church School Education: Moving Beyond the First Two Hundred Years (pp.101-118). London: Bloomsbury.

19 Terry, I. (2012). Church Schools and Anglican Identity. In H. Worsley (Ed.), Anglican Church School Education: Moving Beyond the First Two Hundred Years (pp.119-130). London: Bloomsbury, p.127.

${ }^{20}$ Elbourne, T. (2012). Church School Identity Beyond the Deering Era. In H. Worsley (Ed.), Anglican Church School Education: Moving Beyond the First Two Hundred Years (pp.239-254). London: Bloomsbury.

${ }^{21}$ Wenger, E. (1998). Communities of Practice: Learning, Meaning, and Identity. Cambridge: Cambridge University Press.

${ }^{22}$ Ramadan, T. (2010). The Quest for Meaning: Developing a Philosophy of Pluralism. London: Allen Lane, p.41.
} 
It is not enough to be merely present with students: we must engage with them, to help them become the individuals God intends them to be. There should be contact between those who are different. But simple contact is not enough. Students must be enabled to develop the 'cognitive sophistication' to understand and respect and engage with difference. ${ }^{23}$ Those who are curious will teach themselves, but sometimes an appetite for discovery of difference should be whetted through easily digestible first morsels. As the former Archbishop of Canterbury, Rowan Williams, stated in his 2012 Eid message Christians and Muslims 'have learned how to quarry together the resources we have of a vision of human beings honoured before God.' ${ }^{24}$ But these resources must be put to good use in our schools.

This process of engagement necessarily entails risks. A number of contributors in Ward and Coakley's volume document negative aspects of their experience. ${ }^{25}$ Thus Hughes details his initial personal uncertainty when approached by a Saudi Arabian young man named Mohammed, who wished to discuss and debate the relative merits of Christianity and Islam with him. Fear developed into friendship, a friendship which appears to have been cathartic for Hughes, providing an opportunity to discuss faith with an honesty and openness he did not often experience in parish life. ${ }^{26}$ Similarly Ward recounts her experience as a residentiary canon at Bradford Cathedral, especially the risks involved in her public friendships with Pakistani Muslim women. ${ }^{27}$ In a separate publication Smith documents challenges faced by Christian young people making friends with Muslims. ${ }^{28}$ If these and countless other individuals were not prepared to take risks, hospitality could not be practised, friendships could not develop, communities could not be transformed.

Two examples from my fieldwork will illustrate the point. My first example is of a Polish girl, who arrived in the school aged eight. When I interviewed her that academic year, her main way of referring to Muslims was to talk of them as 'the black people,' whose religious views she had little understanding of or interest in. Many of the Muslims in the school were Somali, as well as a few from Nigeria and Sierra Leone. Her English was not very proficient at this juncture, so her reference may reflect a factual observation inexpertly expressed. When I interviewed her a year later, however, her attitude had changed. She was interviewed together with a Somali Muslim friend, and was now able to explain differing Muslim attitudes to music, including how her Muslim friends would come to her house to listen to

\footnotetext{
${ }^{23}$ Ipgrave, J. 2012. "Relationships between local patterns of religious practice and young people's attitudes to the religiosity of their peers." Journal of Beliefs and Values 33(3), 261-274. DOI 10.1080/13617672.2012.732805

${ }^{24}$ http://rowanwilliams.archbishopofcanterbury.org/articles.php/2597/archbishops-2012-eid-message. Accessed $31^{\text {st }}$ August 2014.

${ }^{25}$ Ward, F. \& Coakley, S. (2012). Fear and Friendship: Anglicans Engaging with Islam. London: Continuum.

${ }^{26}$ Hughes, A. (2012). Fear and Friendship: Conversation or Conversion? In Ward, F. \& Coakley, S. (Eds.) Fear and Friendship: Anglicans Engaging with Islam (pp.3-15). London: Continuum.

${ }^{27}$ Ward, F. (2012). Much Ado About Nothing at Bradford Cathedral. In Ward, F. \& Coakley, S. (Eds.) Fear and Friendship: Anglicans Engaging with Islam (pp.65-78). London: Continuum.

${ }^{28}$ Smith, A. (2009). My Friend Imran. Cambridge: Grove Books.
} 
pop music without their parents knowing. She had moved from indifference to friendship: a clearly transformative encounter.

My second example is of a Somali Muslim boy. According to two teachers whom I interviewed, when this boy first arrived in the school, he refused to participate in RE lessons, covering his ears and saying 'It's haram' (forbidden) whenever the name of Jesus was mentioned. Yet by the time I observed him during my fieldwork, he had to be told to stop reading the New Testament and pay attention during RE lessons, and described the school itself as one that was Christian and 'hosts loads of religions.' He explained to his teacher that when he heard Christian street preachers he would go to them to take any literature they were giving away because he wanted to understand what they believed.

Both of these children had been on transformative journeys from indifference to those who were very different from themselves to an active desire to engage with difference. Such a change could, of course, have taken place in any school, and as I will show below, not every pupil underwent such a positive shift in attitude. Nevertheless, the foundational values of the school made this positive transformation more likely, and Christian hospitality was foundational to making this particular Anglican school a place of transformative encounter.

\section{Supportive Values of respect, forgiveness and freedom}

In the third main section of the paper, I outline three distinct values that support the hospitality offered by the school, namely respect, forgiveness and freedom.

\section{Respect}

Respect is of fundamental importance when encountering difference. We cannot simply tolerate, but must actively respect others. Bretherton suggests there are three conditions necessary for tolerance. First, conduct about which one disapproves, even if only mildly. Second, the disapprover(s), who have the power to act coercively against or interfere with that of which they disapprove, but chose not to. Third, the lack of interference must result from more than acquiescence, indifference or a balance of power. Thus he argues that tolerance is effectively the powerful not wanting something to happen, but choosing to let it happen anyway. ${ }^{29}$ Crane also castigates tolerance, describing it as 'the attitude that I will not kill you now, but I will as soon as I get a good chance,' and arguing that it reflects an understanding derived from medieval toxicology and pharmacology which marked how much poison a body could tolerate before it succumbed to death. ${ }^{30}$ Tolerance is to be welcomed as a first step, a move beyond hatred, but it is no more than that. It is not a peak to ascend, but a foothill from which to climb towards respect.

\footnotetext{
${ }^{29}$ Bretherton, L. (2010). Hospitality as Holiness: Christian Witness Amid Moral Diversity. Farnham: Ashgate, pp.122-126.

${ }^{30}$ Crane, R. D. (2010). From Clashing Civilisations to a Common Vision. In Boase, R. (Ed.) Islam and Global Dialogue: Religious Pluralism and the Pursuit of Peace (pp.159-177). Farnham: Ashgate, p.177.
} 
I observed this to be a feature of how staff interacted with pupils in the school where I did my fieldwork. The headteacher modelled respect by his willingness to allow pupils as young as five teach him how to use the new computers the school bought, and his expectation that he should work harder than all his staff, often staying behind to clear up after whole school events, having sent other staff home. For a Christian, respect is an expression of a Christian worldview that human beings are made in the image of God, and the way we treat others is equivalent to how we treat God himself (Matthew 25:31-46; 1 John 4:19-21).

\section{Forgiveness}

Forgiveness, specifically of those who react negatively when encountering difference, is also central to hospitality. Forgiveness is central to Christianity. As Hauerwas observes: 'God wills nothing less than that men and women should love their enemies and forgive one another; that we will be perfect as God is perfect. ${ }^{31}$ Moreover, it is not simply that we learn to forgive others, but also that we learn to receive forgiveness ourselves, to surrender ourselves to divine care. Forgiveness is never easy. Arnold details examples of those who have managed despite facing terrible situations. ${ }^{32}$ Volf argues that an important part of forgiveness is to remember rightly: neither hating nor disregarding, but loving the wrongdoer. ${ }^{33}$

An example from my fieldwork will illustrate the point. Through the two years of fieldwork, I observed a small group of Somali boys found the school in which I did my fieldwork a difficult place to be in. In one incident, one boy, when being told off by his teacher for not working, responded that since it was 'only a Christian school,' it did not matter how he behaved or whether he did any academic work. On several occasions, the same boy also got into fights with another Somali boy, and again his attitude was that since it was 'only a Christian school,' his behaviour was unimportant. I discussed this boy's behaviour with the headtacher, and he explained his strategy, which had three aspects. First, requesting the boy behave in the school as he would in the mosque, second, involving the boy's parents in any discipline, to reinforce the same message, and third offering forgiveness and a fresh start if the boy was willing to move on. This third element was explained as an outworking of a Christian worldview.

A willingness to forgive is an essential characteristic of a Christian school. Misdemeanours must be punished and discipline must be maintained, but at the same time, there must always be space for forgiveness and a fresh start. The school's reluctance to use exclusion (either fixed term or permanent) as a means of discipline was a further example of the desire to be firm but also forgiving. Without forgiveness, the risk of attempting a transformative encounter may be too great, and people may not develop a sense of belonging. The headteacher explained to me how he had learnt not to offer to shake hands

\footnotetext{
${ }^{31}$ Hauerwas, S. (1983). The Peaceable Kingdom: A Primer in Christian Ethics. London: SCM Press, p.85.

${ }^{32}$ Arnold, J. C. (2000). Why Forgive? Robertsbridge: Plough Publishing House.

${ }^{33}$ Volf, M. (2006). The End of Memory: Remembering Rightly in a Violent World. Grand Rapids: Eerdmans.
} 
with Muslim mothers, primarily by having the offer rebuffed. But he continued to engage with these women, developing his cultural awareness and seeking to be as welcoming as possible. If he had not been willing to continue taking the risk of being rebuffed, and forgiving their often brusque refusals to shake his hand, he could have isolated himself and the school from a significant portion of the wider community.

\section{Freedom}

Third, freedom is also integral to hospitality. By freedom, I am referring to freedom from compulsion or coercion in matters of religion, freedom to believe what you choose. Anglican schools are clear in their own Christian character, but do not force this on anyone, whether they are pupils or staff. As The Way Ahead report explains, it is expected that Anglican schools are

Quietly respectful of the beliefs of others and of other faiths, but confident in its own faith. Church schools will not actively seek to convert children from the faith of their parents, but pupils will experience what it is to live in a community that celebrates the Christian faith; to work within a framework of discipline and yet to be confident of forgiveness; to begin to share the Christian's hope and the Christian experience that the greatest power in life and beyond it is selfless love. ${ }^{34}$

This policy of freedom of belief was modelled during the assemblies which I regularly took in the school. Pupils were free to participate in whatever manner they chose, in particular they were free to opt out of the prayer with which the assembly ended. A member of staff conducted a 'pupil voice' exercise with pupils across the school in preparation for a SIAS inspection ${ }^{35}$ in June 2012 and asked specifically about assemblies. Their responses were as follows:

I like the films that we watch in assemblys and the questions Tom asks us. They make me think (Muslim girl in year three).

We learn about friendship, honesty, God and the Bible (non-Muslim girl in year four).

We learn morals: to learn not to do bad things and to do good things (Muslim girl in year six)

I like praying because it helps me think about what I need to do (Muslim girl in year three).

We pray in assemblies. Some people think and listen if they don't want to pray (non-Muslim boy in year four).

\footnotetext{
${ }^{34}$ Dearing. (2001). The Way Ahead. London: Church House Publishing, p.15.

${ }^{35}$ Statuory Inspection of Anglican Schools, which at the time were conducted a few weeks after Ofsted inspections. Now renamed SIAMS (Statuory Inspection of Anglican and Methodist Schools).
} 
We watch clips of films to help us learn about friendship and lots of other things. Assemblies are good (non-Muslim girl in year five).

Tom says to close your eyes. If you agree you could say amen. You think and pray (Muslim girl in year two).

We learn about religion and God (Muslim boy in year four).

We learn about celebrations like Christmas and Easter. I like Tom's assemblies (Muslim boy in year two).

Tom's assemblies are good because he doesn't just talk, he does things to make them more interesting and to help us learn (non-Muslim girl in year six).

Tom makes us happy and teaches us a lot of things (Muslim boy in year five).

As these responses show, children of a variety of ages and religious perspectives were able to participate in a Christian religious event without being coerced into believing or doing something against their will. Freedom to engage as they chose was also crucial for these pupils' sense of belonging to the diverse school community. Without freedom to believe and engage as they were able, the risk of isolation and ghettoisation was greatly increased.

\section{Conclusion}

Although Anglican schools by no means offer perfect hospitality, they are nevertheless often places that celebrate diversity and promote respectful encounters between those of differing faith traditions. Through creating a safe and secure environment, where there is freedom of belief, a willingness to forgive past mistakes and a respect for difference, Anglican schools can encourage pupils to cross traditional boundaries and engage with one another as people. As Sen notes, we are complex individuals, whose identity has many different facets. ${ }^{36}$ Anglican schools are places where the whole person can devleop and grow in the image of God, and everyone has a genuine opportunity to encounter the hospitality, respect, freedom and forgiveness of Jesus Christ as displayed through those who serve him in that school.

Revd Dr Tom Wilson is vicar of two churches in the centre of Gloucester, in a diverse community which includes a significant Muslim population. He is also Diocesan Inter-faith Advisor for Gloucester Diocese. He has produced several publications from his PhD thesis including a short novel, All United Together (Gloucester: Wide Margin), a Grove Booklet $A$ Theology of Hospitality for Anglican Schools (Cambridge: Grove), as well as an academic monograph, Hospitality and Translation (Newcastle Upon Tyne: Cambridge Scholars Publishing).

\footnotetext{
${ }^{36}$ Sen, A. (2006). Identity and Violence: The Illusion of Destiny. London: Penguin, pp.23-28.
} 